Mojtaba Sadeghi- Ghoghery

Masoud Kasiri- Asgarani

Kamran Amini

DOI: $10.21278 /$ TOF.41107

ISSN 1333-1124

eISSN 1849-1391

\title{
FRICTION STIR WELDING OF DISSIMILAR JOINTS BETWEEN COMMERCIALLY PURE TITANIUM ALLOY AND 7075 ALUMINIUM ALLOY
}

\begin{abstract}
Summary
In this study, a joint between commercially pure titanium alloy and 7075 aluminium alloy was butt welded by using friction stir welding at a rotational speed of $1120 \mathrm{rpm}$ and a traverse speed of $50 \mathrm{~mm} \cdot \mathrm{min}^{-1}$. The evaluation of hardness and microstructure was performed by using scanning electron microscopy. The phases in the weld area were identified by applying the X-ray diffraction technique and the Energy Dispersive X-ray Spectroscopy (EDS) analysis was used for the evaluation of intermetallic compounds of the weld area. The weld zone is cone-shaped and consists of aluminium and titanium particles that play an important role in increasing hardness and tensile strength. The weld area has three zones, namely the titanium base metal zone, the aluminium base metal zone, and the titanium-aluminium intermetallic compound mixed zone. It was also observed that the joint area on the aluminium side includes the stirred area, the thermo-mechanically affected zone, and the heat-affected zone, while the titanium joint area contains the stirred zone and the heat-affected zone. The hardness value of the weld area was around $360 \mathrm{HV}$, which means that in this area, compared to the base metal of titanium and aluminium, hardness has increased by $6 \%$ and $20 \%$, respectively. This can be attributed to severe plastic deformation and formation of intermetallic compounds of titanium and aluminium in this area.
\end{abstract}

Key words: $\quad$ aluminium 7075, pure titanium, friction stir welding, microstructure, mechanical properties

\section{Introduction}

Friction stir welding is a solid state process that is relatively new, efficient in terms of energy consumption, environmentally friendly and versatile. In particular, this method is used for the joining of high-strength aluminium alloys in aerospace industry, for example, in the process of manufacturing a space shuttle external tank [1]. High quality, low residual stress, zero defects, minimum distortion and low cost of joint preparation are considered as the main advantages of this method [2]. Aluminum alloys are widely used in automotive industry, aerospace industry and shipbuilding. Titanium alloys have also attracted much attention in these industries due to their high strength and high corrosion resistance. With the increasing de- 
mand for lightweight equipment, these alloys have been increasingly used. In many applications, superior properties of both aluminium alloys and titanium alloys, such as high strength, low weight and low cost are needed. Because of many differences between these two metals, such as differences in crystal lattice, melting temperature, thermal conductivity, and coefficient of linear expansion, it is very difficult to achieve a defect-free joint between these two alloys [3-4]. The 7075 aluminium alloy, in which zinc is the main alloying element, is a precipitation hardened alloy. It is one of the strongest aluminium alloys which is used in many spatial structures and places that require high strength-to-weight ratio [5-6]. Titanium and its alloys have high specific strength and good corrosion resistance and because of these two desirable properties, they have been widely used in the aerospace industry. Nowadays, due to the increasing application of titanium alloys, the joining of aluminium alloys to titanium alloys has to be considered carefully. The use of conventional fusion welding of titanium leads to the formation of brittleness, distortion and high residual stresses. Therefore, solid state joining processes are more appropriate to avoid problems caused by melting and freezing [7-8]. Friction stir welding is widely used for heat treatable and non-heat treatable aluminium alloys, such as $2 \mathrm{xxx}, 3 \mathrm{xxx}, 5 \mathrm{xxx}$, and $7 \mathrm{xxx}$ series. Some attempts have been made to study friction stir welding on similar and dissimilar alloys, such as the alloy series AA 2024 / 5754 [9], 5086 [10], AA6061 [11-13], AA7075 [14-15], and AA6061 / 7075 [16], as well as on aluminium die casting alloys and aluminium foams [17-22].

Hua et al. [23] studied common characteristics of the interface produced by friction stir welding of aluminium to titanium. They concluded that the interface between aluminium and titanium is severely changed by varying the welding parameters. In this regard, the amount of hardness obtained into the weld zone was around $502 \mathrm{HV}$, which was twice the hardness of aluminium alloy hardness and four times higher than titanium hardness. This increase in hardness was related to the form of the intermetallic compound of titanium-aluminium in the weld area.

Chen et al. [24] studied the properties of the area achieved by the friction stir buttwelding of titanium to aluminium dissimilar alloys. Mechanical properties were derived from the intermetallic compounds. The authors found that the fracture strength of all joints was lower than the fracture strength of the base metal, and in all joints, fracture occurred at the interface of the parts welded. The maximum fracture strength was equal to $9.39 \mathrm{KN}$ for the samples welded at a rotational speed of $1500 \mathrm{rpm}$ and a traverse speed of $90 \mathrm{~mm} \cdot \mathrm{min}^{-1}$.

Desler et al. [25] investigated the butt joint between 2024 aluminium alloy and titanium welded by friction stir welding. The optimal parameters for welding were obtained at a rotation speed of $800 \mathrm{rpm}$ and a traverse speed of $80 \mathrm{~mm} \cdot \mathrm{min}^{-1}$. The stirred zone was a mixture of a recrystallization layer of aluminium and titanium particles. The tensile strength was $73 \%$ higher than that of the aluminium 2024 base metal. This can be attributed to the formation of an aluminium-titanium compound in the weld area.

Bang et al. [26] worked on the friction stir welded butt joint between aluminium 6061 and titanium dissimilar alloys. The stirred area was a mixture of recrystallized particles of titanium and aluminium. A hardness of $350 \mathrm{HV}$ was achieved in the stirred area. Also, the obtained bond strength was $134 \mathrm{MPa}$, which was around $35 \%$ of the strength of the aluminium base metal. All joints had less strength than the base metal because the probe tip was in an area that cannot perform the stirring operation effectively.

Sadeghi et al. [27] studied butt joints between aluminium 5083 and commercially pure titanium dissimilar alloys friction stir welded at a rotation speed of $50 \mathrm{~mm} \cdot \mathrm{min}^{-1}$ and a traverse speed of $1120 \mathrm{~mm} \cdot \mathrm{min}^{-1}$. The hardness of the weld area was $480 \mathrm{HV}$, which was due to the presence of the interphase compounds of aluminium and titanium. 
It is to be noted that there is a limited research on dissimilar joints between commercially pure titanium and 7075 aluminium alloy achieved by friction stir welding. Finally, in this study the effect of the friction stir welding process carried out at a constant rotational speed of $1120 \mathrm{rpm}$ and a traverse speed of $50 \mathrm{~mm} \cdot \mathrm{min}^{-1}$ on hardness, tensile strength, and microstructure of the dissimilar joint between commercially pure titanium and 7075 aluminium alloy are investigated.

\section{Materials and Methods}

Three mm thick sheets of commercially pure titanium (ASTM B265, UNS R50400) [28] and 7075 aluminium alloy (ASTM B209, UNS A97075) [29], whose composition is presented in Tables 1 and 2, were prepared. $120 \mathrm{~mm}$ long and $60 \mathrm{~mm}$ wide pieces were cut from these sheets. Then, to remove grease and surface contaminants, the sheets were washed in acetone and alcohol solutions, and were cleaned ultrasonically. Geometry and dimensions of the welding tool is the most important and influential variable of the friction stir welding process, so that some factors such as welding properties, amount of consumed energy, type of the used device, speed of the process and so on are related to the used tool [30]. Geometry and dimensions of the designed tool are presented in Figure 1. Based on a pervious study, in order to join titanium with aluminium alloy by applying the friction stir welding method, a coneshaped pin was selected [30]. The joint configuration of the present study is a butt joint, which is schematically shown in Figure 2.

Table 1 Chemical composition of commercially pure titanium alloy (weight percentage) [28].

\begin{tabular}{|c|c|c|c|c|c|c|c|c|c|c|c|}
\hline $\mathrm{Ti}$ & $\mathrm{Si}$ & $\mathrm{Zr}$ & $\mathrm{Sn}$ & $\mathrm{Nb}$ & $\mathrm{Mo}$ & $\mathrm{Mn}$ & $\mathrm{Fe}$ & $\mathrm{Cu}$ & $\mathrm{Cr}$ & $\mathrm{V}$ & $\mathrm{Al}$ \\
\hline Base & 0.01 & 0.01 & $0.05<$ & 0.03 & 0.01 & 0.01 & 0.04 & 0.02 & 0.01 & $0.05<$ & 0.01 \\
\hline
\end{tabular}

Table 2 Chemical composition of 7075 aluminium alloy (weight percentage) [29].

\begin{tabular}{|c|c|c|c|c|c|c|c|c|c|c|c|}
\hline $\mathrm{Al}$ & $\mathrm{Zn}$ & $\mathrm{Mg}$ & $\mathrm{Si}$ & $\mathrm{Sn}$ & $\mathrm{Ni}$ & $\mathrm{Co}$ & $\mathrm{Mn}$ & $\mathrm{Fe}$ & $\mathrm{Cu}$ & $\mathrm{Cr}$ & $\mathrm{V}$ \\
\hline Base & 6.36 & 2.77 & 0.108 & 0.01 & 0.005 & 0.003 & 0.281 & 0.175 & 1.61 & 0.277 & 0.0048 \\
\hline
\end{tabular}

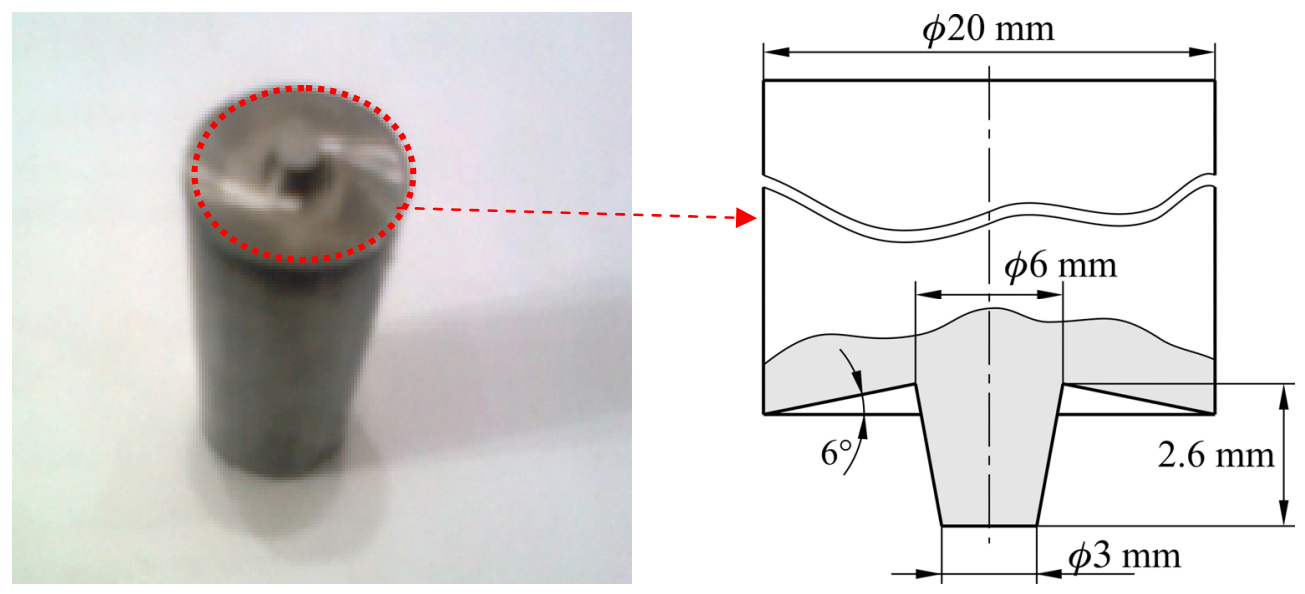

Fig. 1 Scheme of the designed tool. 


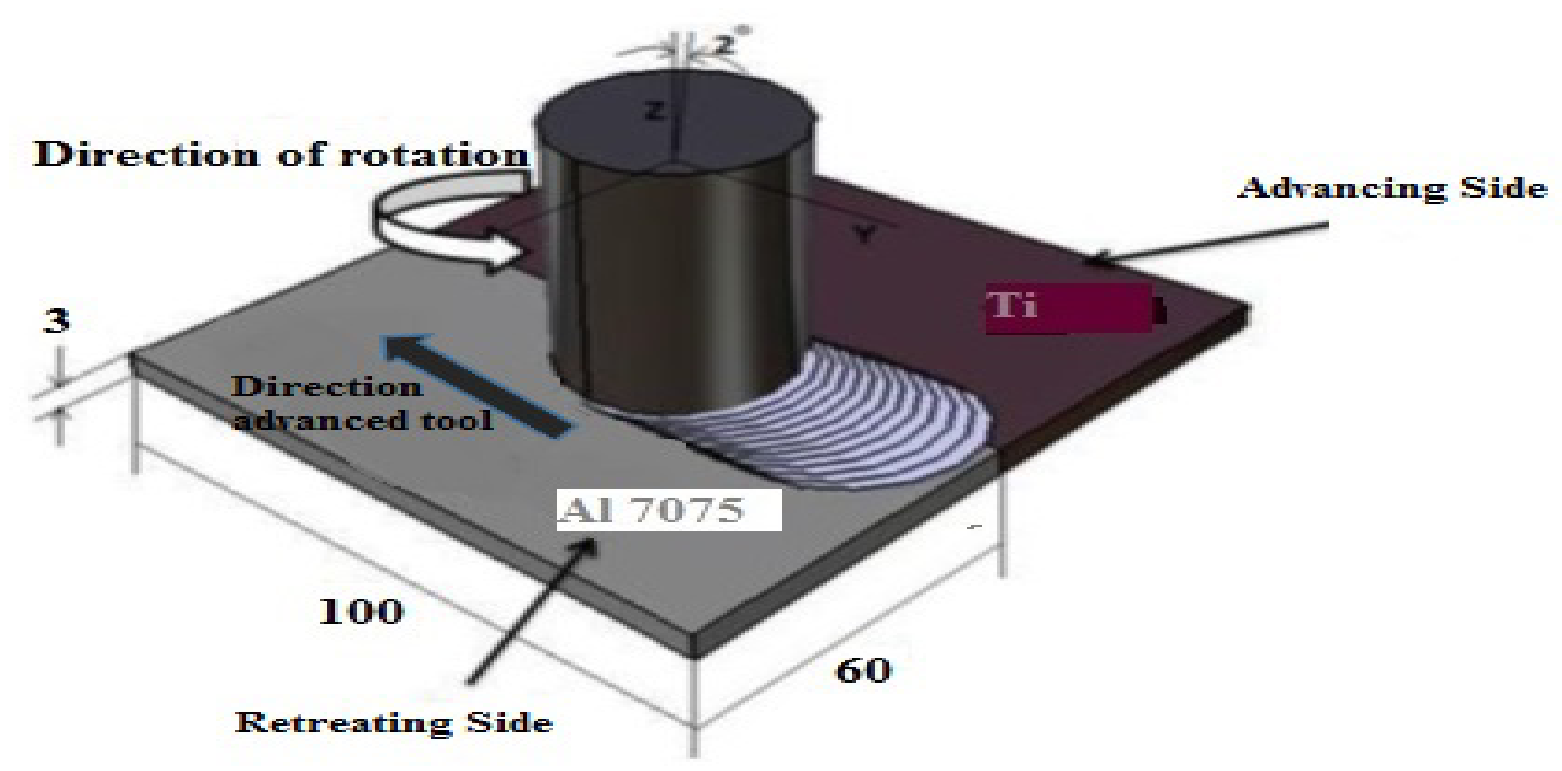

Fig. 2 Scheme of the welding configuration [1].

After fabricating the joints by applying the friction stir welding process, the weldments were exposed to common grinding and polishing processes and they were etched with a solution prepared by mixing $2 \mathrm{ml}$ of $\mathrm{HF}, 4 \mathrm{ml}$ of $\mathrm{HNO}_{3}$, and $94 \mathrm{ml}$ of $\mathrm{H}_{2} \mathrm{O}$ for 40 seconds on the titanium side and the weld zone, as well as $1 \mathrm{ml}$ of $\mathrm{HCl}, 1.5 \mathrm{ml}$ of $\mathrm{HNO}_{3}, 2.5 \mathrm{ml}$ of $\mathrm{HF}$, and $95 \mathrm{ml}$ of $\mathrm{H}_{2} \mathrm{O}$ on the aluminium side. The structure of the welded samples was studied by using optical microscopy (model Nikon) and scanning electron microscopy (model LEO 435 VP). Vickers hardness was obtained using a force of $10 \mathrm{~g}$, and the dwell time of $10 \mathrm{~s}$ was used for measuring hardness. Hardness of the cross-section was measured in nine points for each sample and was reported as the mean value of hardness. Hardness was determined by using a micro hardness testing machine (model Koopa MH1). In order to identify the intermetallic compounds and the created phases, the X-ray diffraction analysis was performed by using a Philips device (model Xpert MPD). In addition to the study on intermetallic compounds, the Energy Dispersive X-ray Spectroscopy (EDS) analysis of the welded area was performed.

\section{Results and Discussion}

\subsection{Titanium microstructure}

Microstructure of this area is presented in Figures $3 \mathrm{a}$ and $3 \mathrm{~b}$. As can be seen, there is a sharp boundary between the stirred area and the heat-affected zone, and thus there is no thermo-mechanically affected area. This is associated with low thermal conductivity of titanium, which results in a lack of heat transfer in the process of welding. Therefore, cooled and more secured areas around the welded area resist the deformation generated by the thermomechanical operation. This means that there is no thermo-mechanically affected zone in titanium and its alloys, which has also been reported by other researchers [7-31-32-33]. In the heat-affected zone, as a result of the thermal cycle, the material has changed in terms of microstructure and mechanical properties and it had finer grains compared to the base metal. 

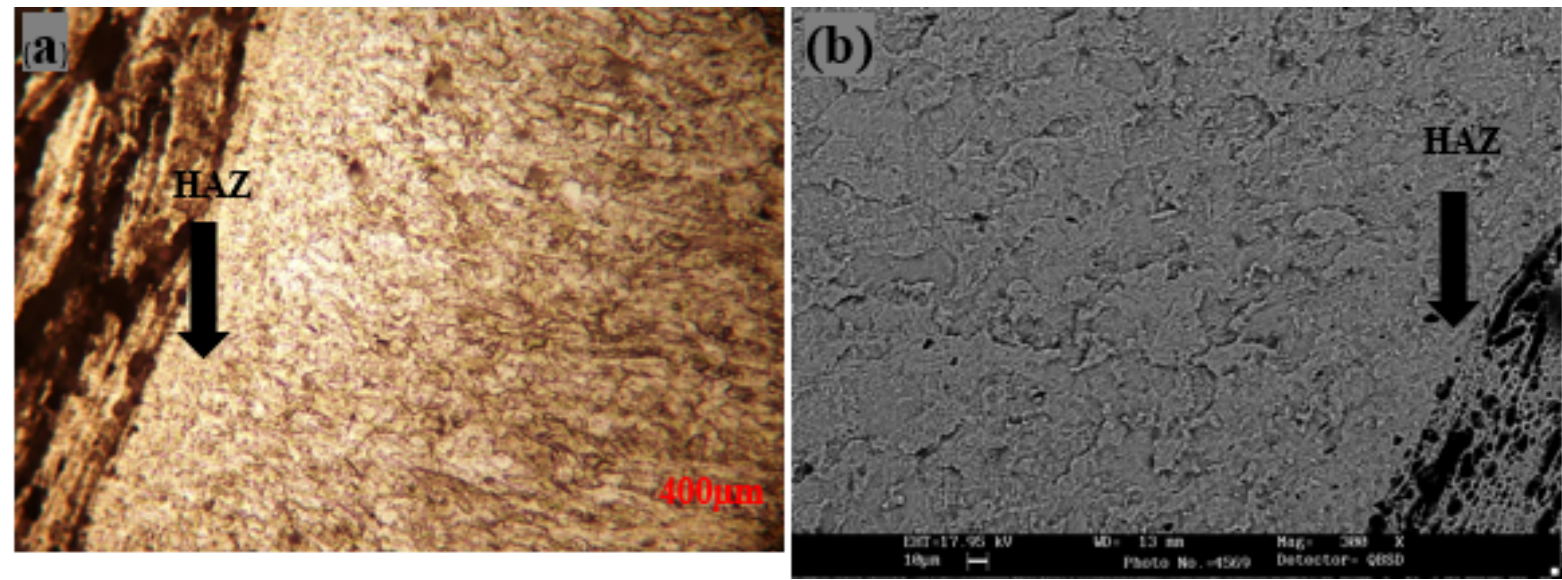

Fig. 3 a) Optical microscope image and b) Scanning electron microscope image of titanium microstructure.

\subsection{Microstructure of 7075 aluminium alloy}

Figures $4 \mathrm{a}$ and $4 \mathrm{~b}$ show the microstructure of $\mathbf{7 0 7 5}$ aluminium alloy. A survey of the images indicates three zones including the stirred zone (SZ), the thermo-mechanically affected zone (TMAZ), and the heat-affected zone (HAZ). The microstructure of the stirred zone includes fine equiaxial and recrystallized grains. The presence of recrystallized and equiaxial grains is one of the main characteristics of friction stir welding that has been reported by other researchers [34]. These grains are formed because of plastic deformation caused by the rotational movement and the progressive tool followed by dynamic recrystallization [35]. In the thermo-mechanically affected zone, deformed and elongated grains are observed. In fact, severe plastic deformation is not enough in this area for dynamic recrystallization to occur and the grains have only become deformed near the stirred zone toward the upper part of the weld area. In the heat-affected zone, as a result of the thermal cycle, the material has changed in terms of microstructure and mechanical properties [34].
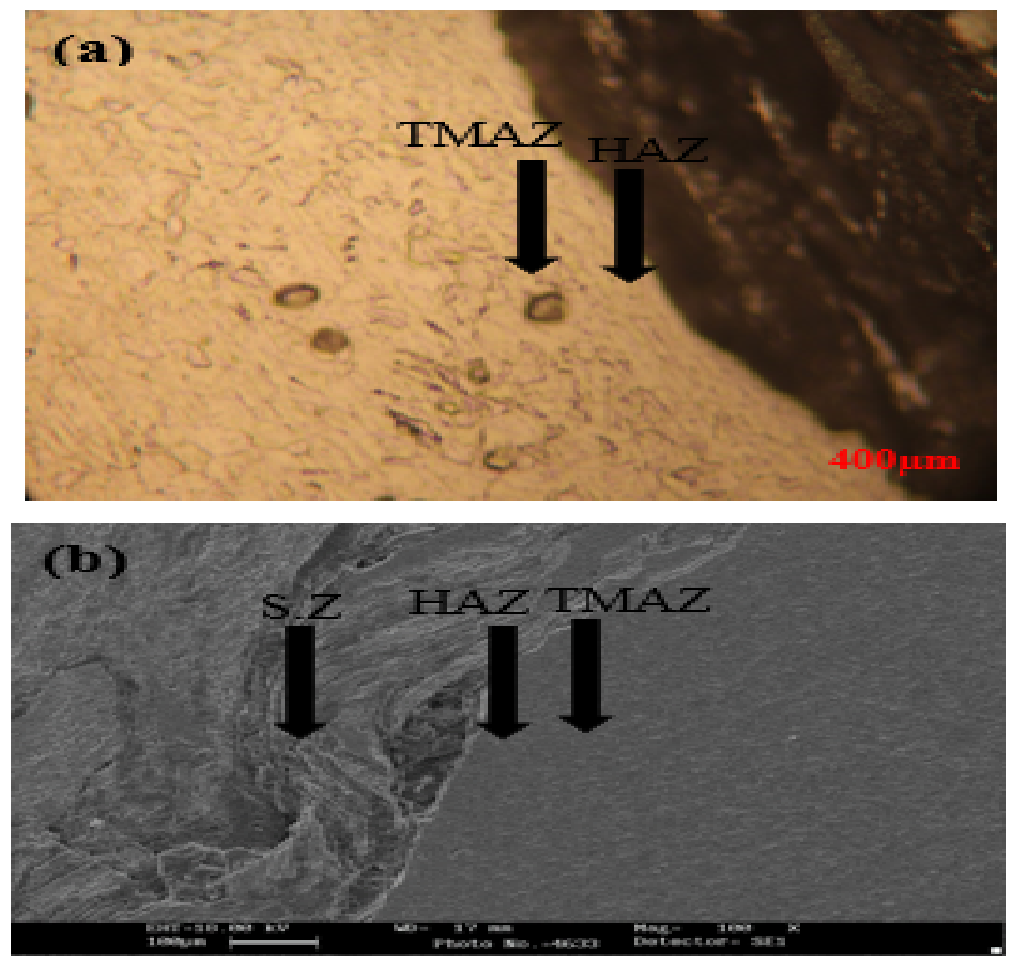

Fig. 4 The image of welding aluminium obtained using a) an optical microscope and b) a scanning electron microscopy. 
M. Sadeghi-Ghogheri,

M. Kasiri- Asgarani, K. Amini
Friction Stir Welding of Dissimilar Joints Between Commercially Pure Titanium Alloy and 7075 Aluminium Alloy

\subsection{The Weld Area}

Microstructure of the welded area is presented in Figures 5a and 5b. As can be observed, the welded area is divided into three different areas, which are specified as areas 1, 2 and 3 . Area 3 is dark and composed of sections. In this region, titanium as a base metal and aluminium alloy have a ratio close to $1: 1$, which represents the formation of the intermetallic titanium and aluminium compound in this area [23]. The morphology of area 1 has a black structure and its type and its elements are very close to aluminium metal, and it explains that the layers of aluminium alloy have entered the intersection by pin forces. The main element in layer 2 is titanium and there is a small amount of aluminium alloy in the form of dispersed particles [23].

In order to identify the elements in the welded area, a part of this area which is marked with $\left(^{*}\right)$ and denoted as (3) in Figure 5, was analysed by EDS, and the obtained results are shown in Figure 6. As can be seen, intermetallic compounds are observed in this area. The results of the X-ray diffraction are given in Figure 7. As can be observed, a variety of intermetallic compounds formed between titanium and aluminium can be identified, and these compounds increase the hardness of the joint. As can also be observed, the intermetallic compounds are distinguished as $\mathrm{Al} \mathrm{Ti} i_{3}, \mathrm{Al} \mathrm{Ti}_{2}$, and $\mathrm{Al}_{2} \mathrm{Ti}$.
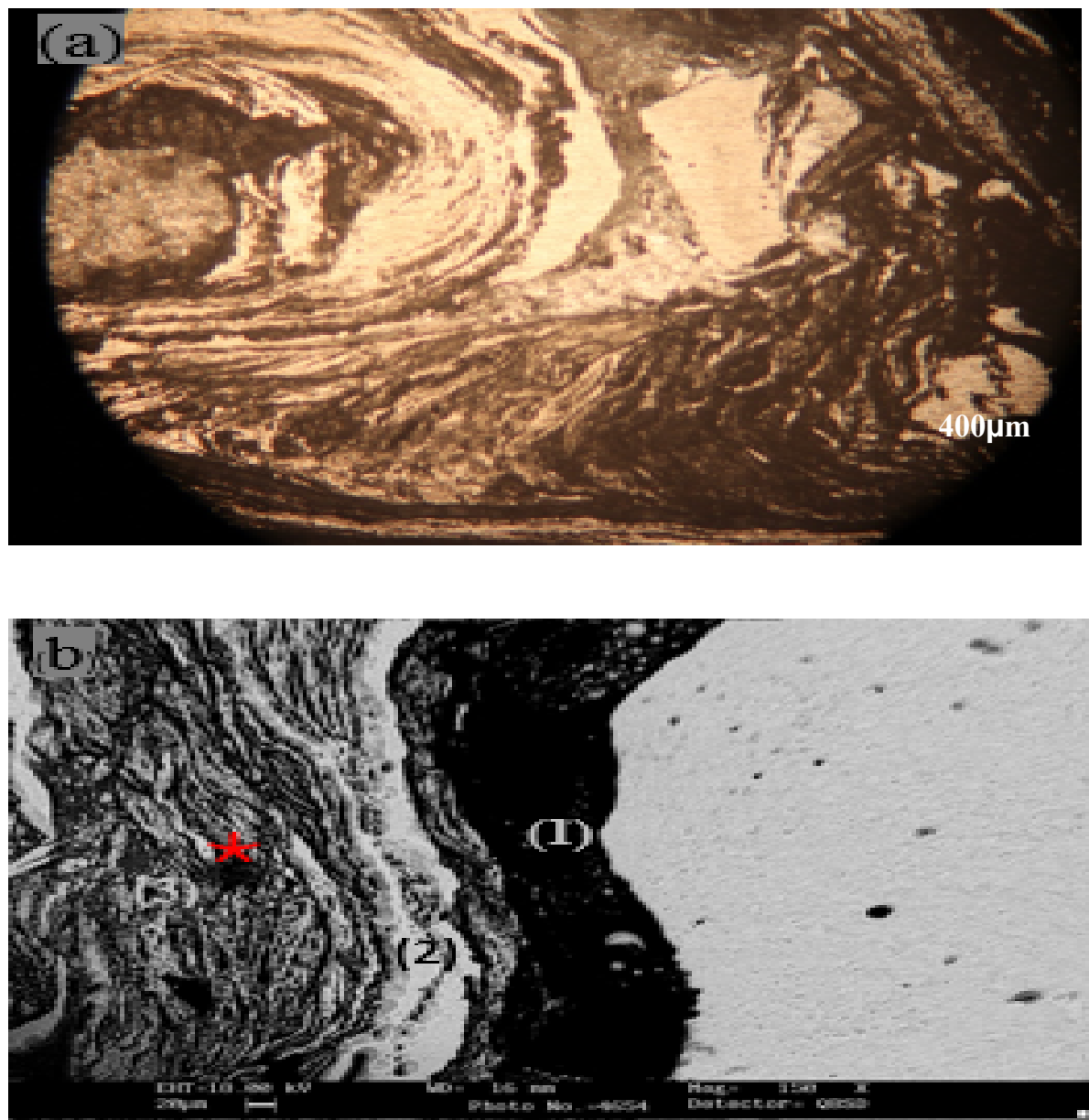

Fig. 5 a) Optical microscope image, b) Scanning electron microscope image of the welded area. 


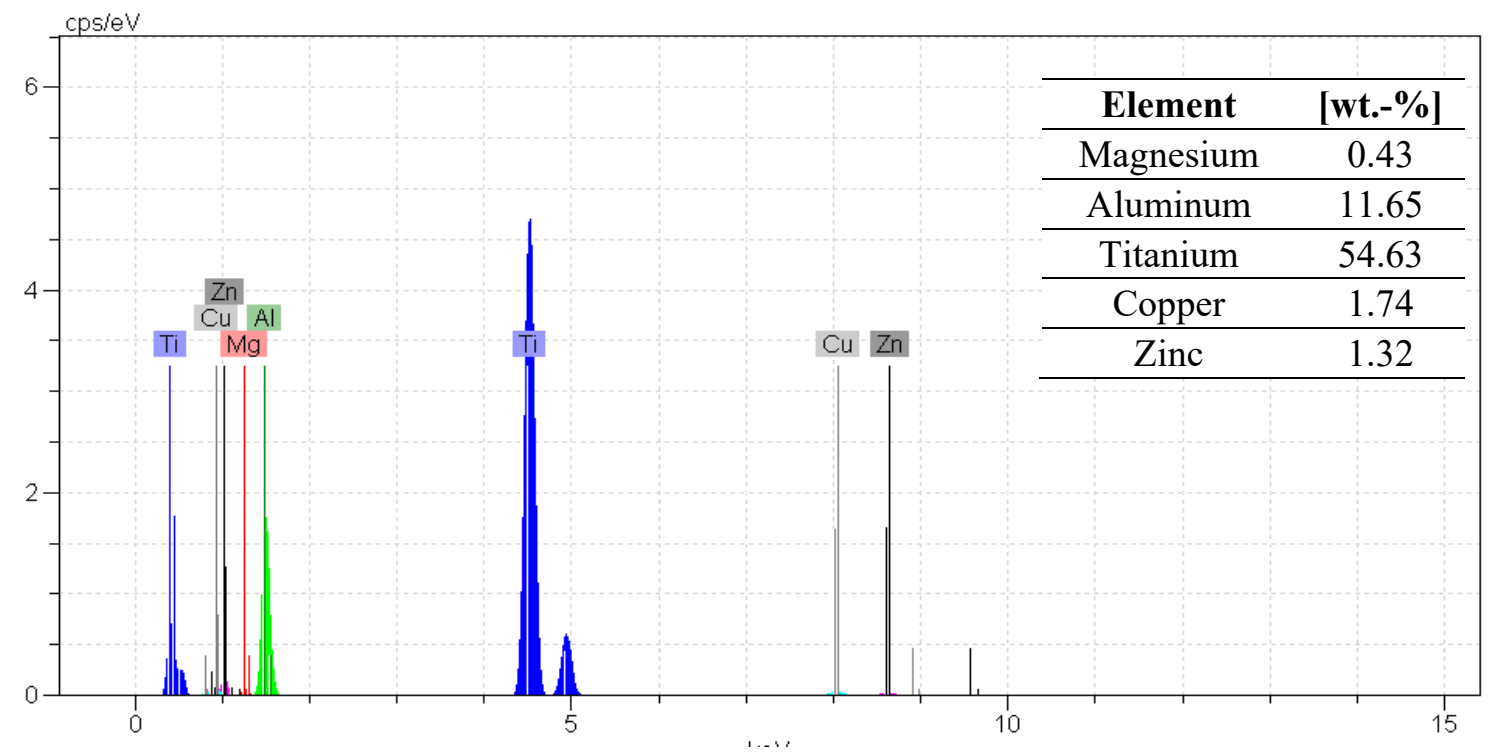

Fig. 6 EDS analysis of the welded area in zone 3.

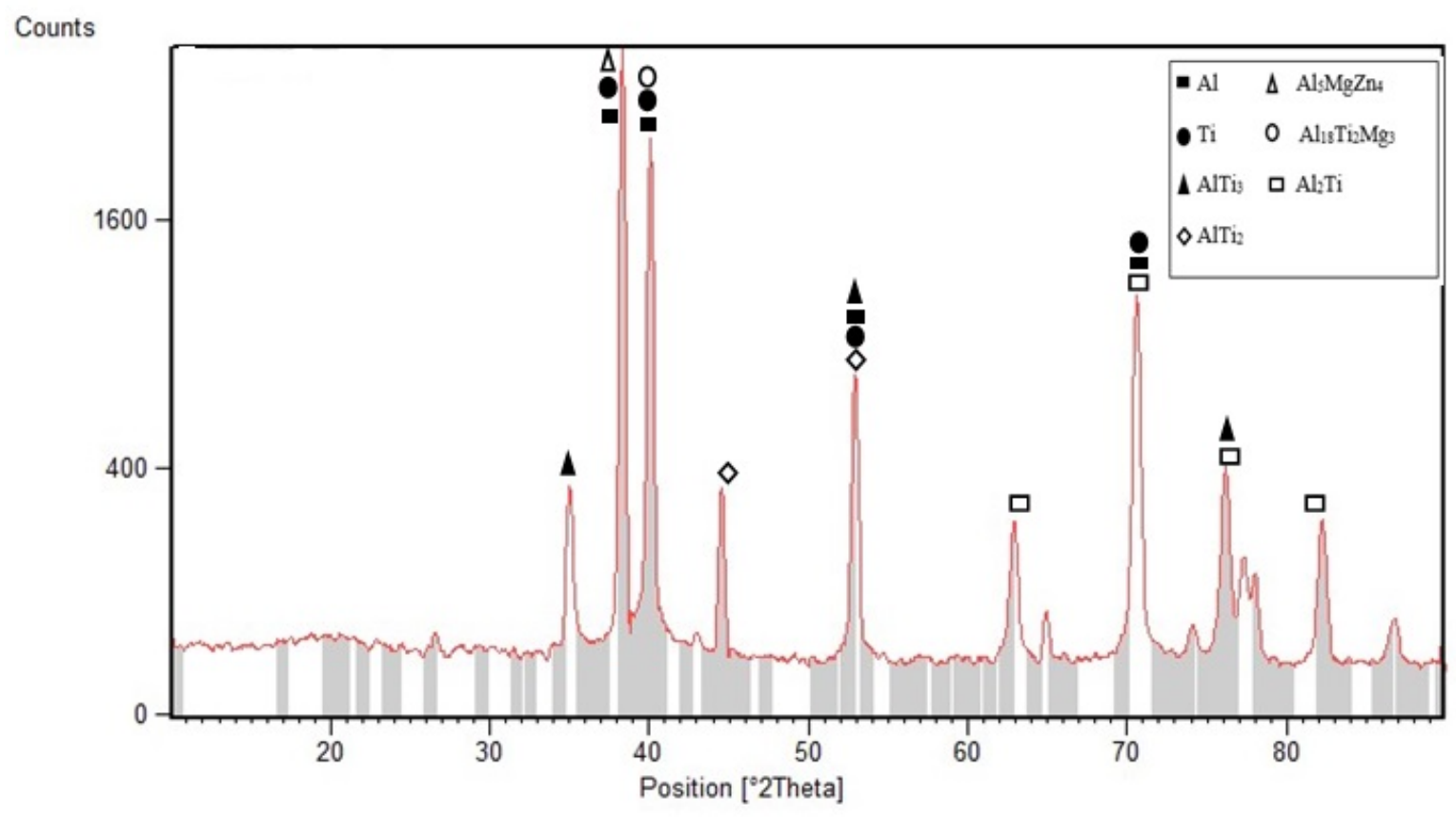

Fig. 7 X-ray diffraction results.

\subsection{Analysis of hardness}

The results obtained from the analysis of hardness of the weldments are shown in Figure 8. As can be observed, in all the weldments, the stirred zone exhibits hardness higher than the heat-affected zone and the base metal has the lowest hardness. This can be attributed to two reasons. Firstly, plastic deformation occurred in the stirred zone and the heat-affected zone, and secondly, the structure of the stirred area is finer than that of the base metal due to dynamic recrystallization in this area. The results showed 360 HV10 hardness in the joint area, which means that the hardness in the area of the titanium base metal and aluminium is increased by $6 \%$ and $20 \%$, respectively. The increase in hardness has been reported by other researchers as well [31-36]. For example, Kitamura showed that smaller particles increase the 
strength of the structure, and that hardness is also directly associated with strength, and as the grains have smaller size in the stirred zone the hardness of the stirred zone increases [36]. Hua also showed that a mixture of aluminium and titanium is formed in the stirred zone, so that the mixed zone is composed of an intermetallic compound and this increases the hardness. $\mathrm{He}$ also reported that hardness in the area reached 502 HV10 [23].

On the titanium side, the minimum hardness, namely $280 \mathrm{HV} 10$, is related to the heataffected zone, which is due to the effect of annealing that leads to softening of this area compared with the base metal [23].

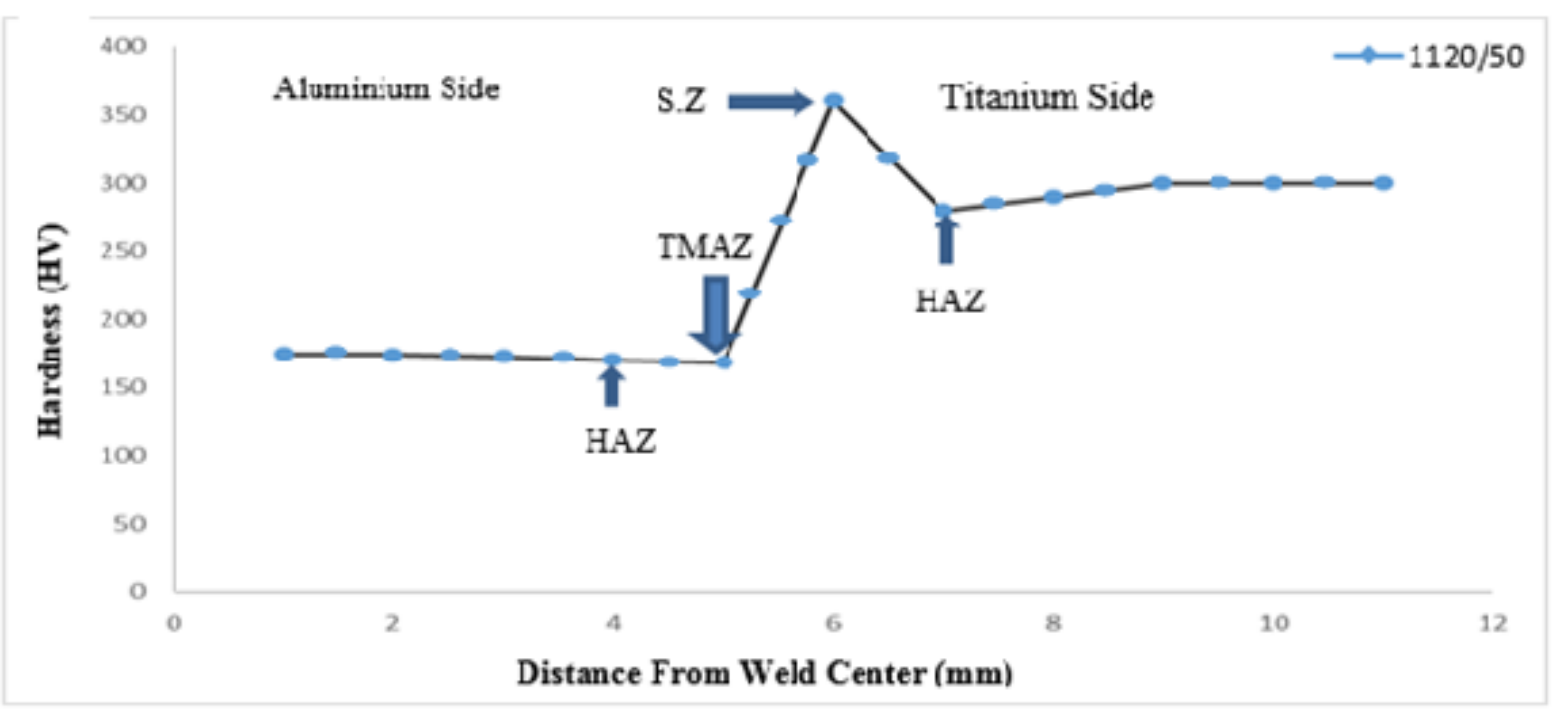

Fig. 8 Hardness profiles with distances from the weld to the base metal of titanium and 7075 aluminium.

\section{Conclusions}

In the stirred zone, the weld microstructure contains three areas: the aluminium base metal, the titanium base metal, and a mechanical mixture of aluminium and titanium. The joint zone on the aluminium side included the stirred zone, the thermo-mechanically affected zone, and the heat-affected zone, while the titanium joint area only included the stirred zone and the heat-affected zones. The maximum hardness is achieved in the stirred zone with a value of $360 \mathrm{HV} 10$ because of plastic deformation that occurs in this zone as well as because of titanium aluminium intermetallic compounds, which are mainly $\mathrm{Al} \mathrm{Ti} i_{3}, \mathrm{Al} \mathrm{Ti}_{2}$, and $\mathrm{Al}_{2} \mathrm{Ti}$.

\section{REFERENCES}

[1] B.T.Gibson, D.H. Lammlein, T.J. Prater, W.R. Longhurst, C.D. Cox, M.C. Ballun, K.J. Dharmaraj, G.E. Cook, A.M. Strauss: Friction stir welding: process, automation and control. Materials and Manufacturing Processes 16, 56-73(2014). DOI: 10.1016/j.jmapro.2013.04.002

[2] A.Salemi Golezani, M. Esmaily, N. Mortazavi: A study on the sub-structure and mechanical properties of friction stir processed AA 6061-T6 joints with ultra-fine grained structure. Advanced Materials and Processing 2, 33-46(2014).

[3] J. Wild, J.P. Bergmann: Manufacturing of titanium/aluminium and titanium/steel joints by diffusion welding. Welding and Cutting 3, 285-290 (2004).

[4] R. Jiangwei, L.I. Yajiang, F. Tao: Microstructure characteristics in the interface zone of Ti/Al diffusion bonding. Materials Letters 56, 647-652(2002). DOI: 10.1016/S0167-577X(02)00570-0

[5] A.H. Feng, D.L. Chen, Z.Y. Ma: Microstructure and cyclic deformation behaviour of a friction-stirwelded $7075 \mathrm{Al}$ alloy. Metallurgical and Materials Transaction A 41, 957-971 (2010).

DOI: $10.1007 / \mathrm{s} 11661-009-0152-3$ 
[6] C. B. Fuller, M.W. Mahoney, M. Calabrese, L. Micona: Evolution of microstructure and mechanical properties in naturally aged 7050 and $7075 \mathrm{Al}$ friction stir welds. Materials Science and Engineering: A 527, 2233-2240 (2010). DOI: 10.1016/j.msea.2009.11.057

[7] W.B. Lee, C.Y. Lee, W.S. Chang, Y.M. Yeon, S.B. Jung: Microstructural Investigation of Friction Stir Welded Pure Titanium. Materials Letters 59, 3315-3318 (2005). DOI: 10.1016/j.matlet.2005.05.064

[8] P.J. Blau: Friction science and technology: from concepts to applications. CRC press, 2008. DOI: $10.1201 / 9781420054101$

[9] Y. Bozkurt, S. Salman, G. Cam: Effect of welding parameters on lap shear tensile properties of dissimilar friction stir spot welded AA 5754-H22/2024-T3 joints. Science and Technology of Welding and Joining 18, 337-345 (2013). DOI: 10.1179/1362171813Y.0000000111

[10] G. Cam, S. Gucluer, A. Cakan, H.T. Serindag: Mechanical properties of friction stir butt-welded Al-5086 H32 plate. Mat -wiss u Werkstofftech 40, 638-642 (2009). DOI: 10.1002/mawe.200800455

[11] G. Cam, G. Ipekoglu, H.T. Serindag: Effects of use of higher strength interlayer and external cooling on properties of friction stir welded AA6061-T6. Science and Technology of Welding and Joining 52, 715720 (2014). DOI: 10.1179/1362171814Y.0000000247

[12] G. Ipekoglu, S. Erim, G. Cam: Investigation into the Influence of Post-Weld Heat Treatment on the Friction Stir Welded AA6061 Al-Alloy Plates with Different Temper Conditions. Metallurgical and Materials Transaction A 45, 864-877(2014). DOI: 10.1007/s11661-013-2026-y

[13] G. Ipekoglu, S. Erim, B.G. Kiral, G. Cam: Investigation into the effect of temper condition on friction stir weldability of AA6061 Al-alloy plates. Kovove Mater 51, 155-163 (2013).

[14] G. Ipekoglu, S. Erim, G. Cam: Effects of temper condition and post weld heat treatment on the microstructure and mechanical properties of friction stir butt-welded AA7075 Al alloy plates. International Journal of Advanced Manufacturing Technology 70, 201-213 (2014). DOI: 10.1007/s00170-013-5255-8

[15] G. Ipekoglu, S. Erim, B.G. Kiral, G. Cam: Investigation of the Effect of Temper Condition on the Friction Stir Weldability of AA7075 Al-Alloy Plates. Materials Technology 46, 627-632 (2012).

[16] A. David, Z. Feng: Friction Stir Welding of Advanced Materials. Materials Science and Engineering: A 252, 2012-2025 (2004).

[17] Y.G, Kim, F. Fujii, T. Tsumura, T. Komazaki, K. Nakata: Three Defect Types in Friction Stir Welding of Aluminum Die Casting Alloy. Materials Science and Engineering: A 415, 250-254 (2006). DOI: 10.1016/j.msea.2005.09.072

[18] M. Jayaraman, R. Sivasubramanian, V. Balasubramanian: Establishing relationship beween the base metal properties and friction stir welding process parameters of cast aluminium alloys, Materials and De-sign, 31, 4567-4576 (2010). DOI: 10.1016/j.matdes.2010.03.040

[19] D. Klobčar, J. Tušek, A. Smolej, S. Simončič: Parametric study of FSSW of aluminium alloy 5754 using a pinless tool, Welding in the World. 59, 269-281 (2015). DOI: 10.1007/s40194-014-0208-X

[20] H. Horn: Friction Stir Welding of Aluminium Foam Materials, Welding in the World-London (2001).

[21] M. Busic: Friction stir welding of aluminium foam sandwich panels, Metalurgija, 168-175 (2015).

[22] Yoshihiko Hangai, Hiroto Kamada, Takao Utsunomiya, Soichiro Kitahara Osamu Kuwazuru, No-buhiro Yoshikawa, Aluminum alloy foam core sandwich panels fabricated from die casting aluminum alloy by friction stir welding route. Journal of Materials Processing Technology. 214, 1928-1934 (2014). DOI: $10.1016 /$ j.jmatprotec.2014.04.010

[23] Hua, CY., Qua, N., Ming, KL.," Interface characteristic of friction stir welding lap joints of Ti/Al dissimilar alloys", Transactions of Nonferrous Metals Society of China, 2, 299-304 (2011).

[24] Chen, Y.C., Nakata, K., "Microstructural Characterization and Mechanical Properties in Friction Stir Welding of Aluminum and Titanium Dissimilar Alloys", Materials and Design, 30, 469-474 (2009). DOI: $10.1016 /$ j.matdes.2008.06.008

[25] U. Dressler, G. Biallas, U.A. Mercado: Friction stir welding of titanium alloy TiAl6V4 to aluminium alloy AA2024-T3. Materials Science and Engineering: A 526, 113-117(2009). DOI: 10.1016/j.msea.2009.07.006

[26] K.S. Bang, K.J. Lee, H.S. Bang: Interfacial Microstructure and Mechanical Properties of Dissimilar Friction Stir Welds between 6061-T6 Aluminum and Ti-6\%Al-4\%V alloys. Materials Transactions 52, 974978 (2011). DOI: 10.2320/matertrans.L-MZ201114

[27] M. Sadeghi- Ghogheri, M. Kasiri- Asgarani, K. Amini: Friction stir welding of dissimilar joint of aluminium alloy 5083and commercially pure titanium. Kovove Mater 54, 71-75 (2016). 
M. Sadeghi-Ghogheri,

M. Kasiri- Asgarani, K. Amini
Friction Stir Welding of Dissimilar Joints Between Commercially Pure Titanium Alloy and 7075 Aluminium Alloy

[28] "Standard specification for Aluminium and Aluminium alloy Sheet and Plate", B-209 (2014), Annual Book of ASTM Standards, 2014.

[29] "Standard specification for Titanium and Titanium alloy Stripe, Sheet and Plate", B-265 (2014), Annual Book of ASTM Standards, 2014.

[30] A. Farias, G.F. Batalha, E.F. Prados, R. Magnabosco, S. Delijaicove: Tool Wear Evaluations In Friction Stir Processing Of Commercial Titanium Ti-6Al-4V. Wear 302, 1327-1333 (2013). DOI: $10.1016 /$ j.wear.2012.10.025

[31] Y. Zhang, Y. S. Sato, H. Kokawa, S. H. C. Park, S. Hirano: Stir Zone Microstructure of Commercial Purity Titanium Friction Stir Welded Using PCBN tool. Materials Science and Engineering: A 488, 25-30 (2008). DOI: 10.1016/j.msea.2007.10.062

[32] H.J. Liu, L. Zhou, Q.W. Liu: Microstructural characteristics and mechanical Properties of Friction stir Welded joints of Ti-6Al-4V titanium alloy. Materials and Design 31, v1650-1655(2010). DOI: 10.1016/j.matdes.2009.08.025

[33] L. Zhou, H.J. Liu, Q.W. Liu: Effect of Rotation Speed on Microstructural and Mechanical Properties of Ti-6Al-4V Friction Stir Welded Joints titanium. Materials and Design 31, 2631-2636 (2010). DOI: $10.1016 /$ j.matdes.2009.12.014

[34] R.S. Mishra, Z.Y. Ma: Friction Stir Welding and Processing. Materials Science and Engineering: R 50, 17 (2005). DOI: 10.1016/j.mser.2005.07.001

[35] M.K. Kulekci, U. Esme, B. Buldum: Critical analysis of friction stir-based manufacturing processes. The International Journal of Advanced Manufacturing Technology, 1-26 (2015).

[36] K. Kitamura, H. Fujii, Y. Iwata, Y.S. Sun, Y. Morisada: Flexible Control of the Microstructural and mechanical Properties of Friction stir Welded of Ti-6Al-4V joints. Materials and Design 46, 348-354 (2012). DOI: $10.1016 /$ j.matdes.2012.10.051

Submitted: $\quad 26.3 .2016$

Accepted: $\quad 22.7 .2016$
Mojtaba Sadeghi- Ghoghery

Dr. Masoud Kasiri- Asgarani*

m.kasiri.a@gmail.com

Advanced Materials Research Center, Department of Materials Engineering, Najafabad Branch, Islamic Azad University, Najafabad, Iran

Dr. Kamran Amini * kamran_amini1978@hotmail.com Advanced Materials Research Center, Department of Materials Engineering, Najafabad Branch, Islamic Azad University, Najafabad, Iran Department of Mechanical Engineering, Tiran Branch, Islamic Azad University, Isfahan, Iran

*Corresponding Author 